\title{
Pengaruh Jenis Pupuk dan Dekomposer terhadap Pertumbuhan dan Produksi Padi Organik
}

\author{
The Influence of Fertilizer Types and Decomposer on Organic Rice Growth and Yield
}

\author{
Arinal Haq Izzawati Nurrahma, Maya Melati*
}

Departemen Agronomi dan Hortikultura, Fakultas Pertanian, Institut Pertanian Bogor

(Bogor Agricultural University), Jl. Meranti, Kampus IPB Darmaga, Bogor 16680, Indonesia

\begin{abstract}
The objective of the research was to study the effect of fertilizer types and decomposer on growth and yield of organic rice Field experiment was carried out in Cikarawang, Dramaga, Bogor from November 2011 to March 2012.. The experiment used factorial-randomized complete block design with fertilizer combinations (15 ton chicken manure $h a^{-1}$ and 5 ton Tithonia diversifolia $\mathrm{ha}^{-1}, 10$ ton chicken manure ha ${ }^{-1}$ and 5 ton $\underline{\text { T. diversifolia }}$ $h a^{-1}$, and 10 ton chicken manure $h a^{-1}$ and 5 ton rice straw hal ${ }^{-1}$ ) as the first factor and decomposer application (using decomposer and without decomposer) as the second factor. Organic fertilizer types significantly affected root wet weight, nutrient content of $P$ and $K$ in leaves. Rice yields were not significantly different with fertilizer combinations 15 ton chicken manure $h a^{-1}$ and 5 ton T. diversifolia $h a^{-1}, 10$ ton chicken manure ha ${ }^{-1}$ and 5 ton $\underline{T}$. diversifolia $h a^{-1}$, and 10 ton chicken manure $h a^{-1}$ and 5 ton rice straw $h a^{-1}$, they were 2.28, 2.22, and 2.16 ton dry seed $h^{-1}$, respectively. Decomposer application significantly affected the number of tillers at 8 week after planting, leaf color at 5 weeks after planting, nutrient content of $P$ in leaves and panicle length. Rice yield with decomposer application and without decomposer were 2.25 and 2.19 ton ha ${ }^{-1}$, respectively, and they were not different.
\end{abstract}

Keywords: chicken manure, decomposer, organic rice, rice straw, Tithonia diversifolia

\section{ABSTRAK}

Tujuan dari penelitian ini adalah untuk mempelajari pengaruh jenis pupuk dan aplikasi dekomposer terhadap pertumbuhan dan produksi padi organik.Penelitian dilakukan di Cikarawang, Dramaga, Bogor dari bulan November 2011 hingga Maret 2012. Penelitian menggunakan Rancangan Kelompok Lengkap Teracak Faktorial dengan jenis pupuk (15 ton pupuk kandang ayam ha ${ }^{-1}$ dengan 5 ton Tithonia diversifolia ha ${ }^{-1}, 10$ ton pupuk kandang ayam ha-1 dengan 5 ton T. diversifolia ha ${ }^{-1}$, dan 10 ton pupuk kandang ayam ha ${ }^{-1}$ dengan 5 ton jerami $\mathrm{ha}^{-1}$ ) sebagai faktor pertama dan aplikasi dekomposer (dengan dan tanpa dekomposer) sebagai faktor kedua. Jenis pupuk organik berpengaruh signifikan terhadap bobot basah akar, kadar P dan K dalam daun. Produktivitas padi dari kombinasi 15 ton pupuk kandang ayam ha-1 dengan 5 ton T. diversifolia ha ${ }^{-1}, 10$ ton pupuk kandang ayam haldengan 5 ton T. diversifolia ha $\mathrm{h}^{-1}$, dan 10 ton pupuk kandang ayam ha $\mathrm{a}^{-1}$ dengan 5 ton jerami padi $h a^{-1}$ masing-masing adalah 2.28, 2.22, dan 2.16 ton gabah kering per hektar. Aplikasi dekomposer meningkatkan jumlah anakan 8 minggu setelah tanam, warna daun 5 minggu setelah tanam, kadar P pada daun dan panjang malai. Produktivitas padi dengan aplikasi dekomposer dan tanpa dekomposer tidak berbeda nyata dan secara berurutan adalah 2.25 dan 2.19 ton $\mathrm{ha}^{-1}$.

Kata kunci: pupuk kandang ayam, dekomposer, padi organik, jerami padi, Tithonia diversifolia

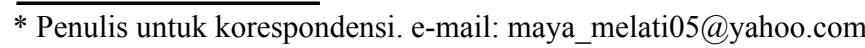




\section{PENDAHULUAN}

Padi (Oryza sativa L.) merupakan sumber makanan pokok utama masyarakat Indonesia. Seiring peningkatan laju pertumbuhan penduduk, kebutuhan berasjuga semakin meningkat. Inimerupakantantangan bagi petani untuk mencari pilihan teknologi yang mampu mencukupi kebutuhan pangan dengan kualitas baik dan menyehatkan tetapi tidak menimbulkan kerusakan lingkungan. Salah satu pilihan teknologi yang saat ini mulai banyak diterapkan petani adalah sistem budidaya organik. Pertanian organik menuntut penggunaan bahan alami sebagai input produksi yaitu penggunaan pupuk organik untuk meningkatkan kesuburan tanah.

Pupuk organik terdiri dari berbagai sumber bahan organik yang beragam pola mineralisasinya, kandungan hara, dan ketersediaannya. Pupuk kandang relatif mudah diperoleh dari suatu peternakan (Munawar, 2011). Jerami merupakan bagian dari tanaman padi yang tidak ikut diambil saat panen (Makarim et al., 2007). Tithonia diversifolia merupakan gulma yang banyak ditemui sebagai semak di pinggir jalan, tebing, dan sekitar lahan pertanian mengandung $3.50 \% \mathrm{~N}$, $0.37 \%$ P, dan $4.10 \%$ K (Hartatik, 2007). Ketiga jenis bahan tersebut memiliki kandungan unsur N, P dan $\mathrm{K}$ yang baik digunakan sebagai pupuk organik sesuai tingkat ketersediaannya di lapang.

Dekomposer merupakan mikroorganisme pengurai atau perombak nitrogen dan karbon dari jaringan tumbuhan atau hewan yang telah mati, sehingga proses mineralisasi berjalan lebih cepat dan penyediaan hara bagi tanaman lebih baik (Saraswati et al., 2006). Pengomposan berbagai jenis pupuk dengan aplikasi dekomposer dilakukan di lahan penanaman agar dapat digunakan langsung setelah terdekomposisi dan tidak membutuhkan tempat khusus.

Penelitian ini bertujuan untuk mempelajari pengaruh jenis pupuk, dekomposer dan interaksi keduanya dalam budidaya padi secara organik.

\section{BAHAN DAN METODE}

Penelitian dilaksanakan pada bulan November 2011 hingga Maret 2012 di Kebun Percobaan Cikarawang, Dramaga, Bogor. Analisis tanah dan analisis jaringan tanaman dilakukan di Laboratorium Kimia Tanah Departemen Ilmu Tanah dan Sumber Daya Lahan, Fakultas Pertanian, Institut Pertanian Bogor.

Bahan yang digunakan adalah benih padi varietas Ciherang, $T$. diversifolia, pupuk kandang ayam, jerami, dan abu sekam. Dekomposer yang digunakan mengandung beberapa mikroorganisme perombak yaitu Lactobacillus sp., Streptomyces sp., Eschericia coli, Bacillus sp., dan Trichoderma sp. Alat yang digunakan adalah alat budidaya tanaman.

Penelitian ini menggunakan Rancangan Kelompok Lengkap Teracak (RKLT) Faktorial dengan dua faktor. Faktor pertama kombinasi pupuk 15 ton pupuk kandang ayam per hektar +5 ton $T$. diversifolia per hektar, 10 pupuk kandang ayam per hektar +5 ton T. diversifolia per hektar, dan 10 ton pupuk kandang ayam per hektar +5 ton jerami per hektar. Faktor kedua aplikasi dekomposer, yaitu tanpa aplikasi dan dengan aplikasi dekomposer. Terdapat enam kombinasi perlakuan dengan empat kali ulangan, sehingga terdapat 24 satuan percobaan. Luasan petak yang digunakan adalah $3 \mathrm{~m} \times 3 \mathrm{~m}$. Data dianalisis dengan sidik ragam, dan apabila perlakuan berpengaruh nyata, dilakukan uji lanjut DMRT (Duncan Multiple Range Test) pada taraf kesalahan 5\%.

Sebagai perbandingan dilakukan penanaman padi dengan perlakuan 10 ton jerami dengan 5 ton pupuk kandang ayam per hektar dan 0.4 ton pupuk kandang ayam per hektar yang dicairkan sebagai dekomposer, 10 ton jerami dan 5 ton pupuk kandang ayam per hektar dengan aplikasi dekomposer, dan 10 ton jerami dengan 5 ton pupuk kandang ayam per hektar (P3). Luasan petakan tambahan adalah $5 \mathrm{~m}$ x $5 \mathrm{~m}$ sebanyak 3 petakan, tanpa ulangan. Khusus membandingkan perlakuan dengan ketiga pembanding, dilakukan uji tstudent pada taraf $5 \%$.

Pengolahan tanah dilakukan dengan membersihkan lahan dari gulma lima minggu sebelum tanam bersamaan dengan aplikasi pupuk sesuai perlakuan. Aplikasi dekomposer dilakukan dua minggu setelah aplikasi pupuk sesuai perlakuan. Dekomposer sebanyak $0.5 \%$ per bahan baku dilarutkan dalam 5 liter air kemudian disiramkan secara merata pada pupuk organik yang telah disebar dilahan.

Bibit berumur 21 HST ditanam sebanyak 3 tanaman per lubang dengan jarak tanam $30 \mathrm{~cm}$ x $30 \mathrm{~cm}$. Penyulaman dilakukan seminggu setelah pindah tanam untuk mengganti bibit yang mati atau pertumbuhannya kurang baik di lahan sawah.

Penambahan pupuk kandang dilakukan pada semua petak percobaan dengan dosis 5 ton per hektar dengan cara ditebar karena terlihat gejala defisiensi hara pada tanaman. Penyemprotan pestisida nabati dan agen hayati dilakukan secara terbatas disesuaikan dengan serangan OPT yang muncul.

Peubah yang diamati adalah tinggi tanaman, jumlah anakan, warna daun, panjang akar, bobot kering dan basah biomassa akar dan tajuk, jumlah anakan produktif, panjang malai, jumlah gabah per 
malai, bobot basah dan kering gabah per tanaman, persentase gabah isi dan hampa, bobot 1,000 butir, bobot petak bersih basah dan kering, potensi hasil dan produktivitas dan kadar hara N, P dan K pada daun.

\section{HASIL DAN PEMBAHASAN}

Berdasarkan data iklim Stasiun Klimatologi Dramaga Bogor, selama penelitian berlangsung curah hujan tiap bulannya berkisar antara 136-548.9 mm, kelembaban berkisar antara $80-87 \%$, temperatur antara $25.1-26.2^{\circ} \mathrm{C}$ dengan intensitas penyinaran rata-rata $330.92 \mathrm{Cal} \mathrm{cm}^{-2}$.

Hasil analisis tanah yang dilakukan pada awal penelitian menunjukkan $\mathrm{pH}$ tanah netral (6.60). Komposisi kandungan liat $54.48 \%$, kandungan debu $35.58 \%$, dan kandungan pasir $9.94 \%$. Kandungan Corganik dan N-totalnya rendah, yaitu sebesar $1.76 \%$ dan $0.18 \%$ sehingga $\mathrm{C} / \mathrm{N}$ rasionya juga terbilang rendah (9.77). Nilai kejenuhan basa sebesar $88.49 \%$ tergolong sangat tinggi dan nilai KTK tanah sebesar

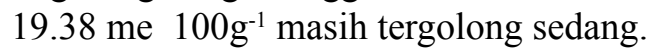

Sejarah lahan sebelumnya digunakan untuk budidaya padi konvensional, dilanjutkan dua musim tanam kedelai organik, jagung manis, ubi jalar dan diberakan selama beberapa bulan sebelum digunakan untuk penelitian ini. Irigasi menggunakan air sungai yang terlebih dahulu melalui petak kecil berisi eceng gondok. Serangan hama dan penyakit terjadi hampir pada setiap fase pertumbuhan. Beberapa diantaranya yang cukup mengganggu tanaman adalah hawar daun bakteri (bacterial leaf blight), walang sangit (Leptocorisa oratorius), penggerek batang dan burung.

\section{Pengaruh Jenis Pupuk Organik}

Jenis pupuk organik berpengaruh nyata terhadap beberapa peubah pada komponen pertumbuhan (Tabel 1) namun tidak memberikan pengaruh nyata terhadap peubah pada komponen produksi tanaman (Tabel 2). Pemberian 5 ton T. diversifolia dengan 15 ton pupuk kandang ayam per hektar meningkatkan bobot basah akar per tanaman $54.26 \%$ lebih tinggi dibandingkan dengan perlakuan lainnya.

Perlakuan 5 ton jerami ha ${ }^{-1}$ dengan 10 ton pupuk kandang ayam ha ${ }^{-1}$ menyebabkan kadar hara $\mathrm{P}$ dan $\mathrm{K}$ $10.52 \%$ dan $12.19 \%$ lebih tinggi dibandingkan dengan pemberian 5 ton $T$. diversifolia dengan 15 ton pupuk kandang ayam per hektar dan 5 ton $T$. diversifolia dengan 10 ton pupuk kandang ayam per hektar (Tabel 1). Kandungan hara $\mathrm{K}$ pada daun yang terbaik adalah pada tanaman padi yang diberi kombinasi pupuk 10 ton pupuk kandang dan 5 jerami per hektar yaitu sebesar $3.22 \%$. Hal ini disebabkan jerami mengandung $\mathrm{K}$ yang tinggi dan baik digunakan sebagai sumber hara K. Hanafiah (2005) dan Munawar (2011) menyatakan bahwa tanaman legum unggul dalam kadar $\mathrm{Ca}$ dan $\mathrm{N}$, juga unsur $\mathrm{Mg}, \mathrm{Na}, \mathrm{P}, \mathrm{S}$ dan $\mathrm{Cl}$, sedangkan tanaman graminae unggul dalam kadar $\mathrm{K}$.

\section{Pengaruh Aplikasi Dekomposer}

Pemberian dekomposer meningkatkan jumlah anakan per rumpun sebesar $11.03 \%$ dan kadar hara $P$ pada daun sebesar 5.26\% lebih baik dibandingkan tanpa pemberian dekomposer (Tabel 3). Pemberian dekomposer meningkatkan panjang malai $23.76 \mathrm{~cm}$ serta $3.71 \%$ lebih baik dibandingkan tanpa pemberian dekomposer (Tabel 4).

Aplikasi dekomposer diduga mampu meningkatkan ketersediaan $\mathrm{P}$ dalam tanah.

Tabel 1. Komponen pertumbuhan padi pada perlakuan tiga jenis kombinasi pupuk organik

\begin{tabular}{|c|c|c|c|c|c|}
\hline \multirow[t]{2}{*}{ Peubah } & \multirow{2}{*}{$\begin{array}{l}\text { Umur } \\
\text { (MST) }\end{array}$} & \multirow[t]{2}{*}{ Uji F } & \multicolumn{3}{|c|}{ Kombinasi pupuk (ton ha-1) } \\
\hline & & & $\begin{array}{l}5 \mathrm{TD}+ \\
15 \mathrm{PA}\end{array}$ & $\begin{array}{c}5 \mathrm{TD}+ \\
10 \mathrm{PA}\end{array}$ & $\begin{array}{c}5 \mathrm{~J}+10 \\
\mathrm{PA}\end{array}$ \\
\hline \multirow{2}{*}{$\begin{array}{l}\text { Tinggi tanaman } \\
(\mathrm{cm})\end{array}$} & 8 & tn & 74.5 & 72 & 73.8 \\
\hline & 14 & tn & 94.1 & 90.1 & 93 \\
\hline \multirow{2}{*}{$\begin{array}{l}\text { Jumlah anakan } \\
\text { per rumpun }\end{array}$} & 8 & tn & 13.7 & 14.7 & 14.7 \\
\hline & 14 & tn & 11.6 & 11.7 & 11.6 \\
\hline Warna daun & 8 & tn & 3.06 & 3.03 & 3.06 \\
\hline $\begin{array}{l}\text { BB tajuk } \\
\text { (g tanaman-1) }\end{array}$ & 8 & $\operatorname{tn} x)$ & 135.88 & 92 & 102.25 \\
\hline $\begin{array}{l}\text { BB akar } \\
\text { (g tanaman-1) }\end{array}$ & 8 & $* \mathrm{x})$ & $55.75 \mathrm{a}$ & $29.75 b$ & $36.12 b$ \\
\hline $\begin{array}{l}\text { BK akar } \\
\text { (g tanaman-1) }\end{array}$ & 8 & $\operatorname{tn} x)$ & 16.35 & 8.76 & 8.08 \\
\hline $\begin{array}{l}\text { Panjang akar } \\
(\mathrm{cm})\end{array}$ & 8 & tn & 27.56 & 26.62 & 30.19 \\
\hline \multicolumn{6}{|c|}{ Kadar hara pada daun: } \\
\hline N (\%) & 8 & tn & 0.95 & 1.02 & 0.85 \\
\hline $\mathrm{P}(\%)$ & 8 & $* *$ & $0.36 \mathrm{c}$ & $0.38 \mathrm{~b}$ & $0.42 \mathrm{a}$ \\
\hline K $(\%)$ & 8 & $* *$ & $2.58 \mathrm{~b}$ & $2.87 \mathrm{~b}$ & $3.22 \mathrm{a}$ \\
\hline \multicolumn{6}{|c|}{ Serapan hara (g tanaman-1): } \\
\hline N & 8 & $\operatorname{tn} x)$ & 0.34 & 0.23 & 0.21 \\
\hline $\mathrm{P}$ & 8 & $\operatorname{tn} x)$ & 0.12 & 0.08 & 0.11 \\
\hline K & 8 & $\operatorname{tn} x)$ & 0.89 & 0.67 & 0.82 \\
\hline
\end{tabular}

Keterangan: (tn) Tidak berbeda nyata; $(*)$ Berbeda nyata pada taraf kesalahan $5 \% ;(* *)$ Berbeda nyata pada taraf kesalahan $\left.1 \% ;{ }^{x}\right)$ hasil transformasi $\sqrt{ }(\mathrm{x}+0.5), \mathrm{BK}=$ bobot kering, $\mathrm{BB}=$ bobot basah, $\mathrm{TD}=T$. diversifolia, $\mathrm{PA}=$ pupuk kandang ayam, $\mathrm{J}=$ jerami 
Bul. Agrohorti 1 (1) : 149 - 155 (2013)

Tabel 2. Komponen produksi padi pada perlakuan tiga jenis pupuk organik

\begin{tabular}{lccccc}
\hline Peubah & Umur & Uji F & \multicolumn{3}{c}{ Kombinasi pupuk (ton ha ${ }^{-1}$ ) } \\
\cline { 5 - 6 } & (MST) & & 5 TD + 15 PA & 5 TD + 10 PA & 5 J + 10 PA \\
\hline Jumlah anakan produktif & 14 & tn & 10.9 & 11.3 & 11.1 \\
Jumlah malai & 14 & tn & 10.0 & 10.5 & 10.5 \\
Jumlah gabah per malai & 14 & tn & 131.80 & 123.9 & 131.6 \\
Bobot 1000 butir (g) & 14 & tn & 28.72 & 28.33 & 29.11 \\
Gabah isi (\%) & 14 & tn & 86.17 & 87.33 & 88.73 \\
BB gabah petak bersih (kg 7.29m-2) & 14 & tn & 1.67 & 1.57 & 1.59 \\
BK gabah petak bersih (kg 7.29m-2) & 14 & tn & 1.42 & 1.35 & 1.39 \\
Produktivitas GKG (ton ha-1) & 14 & tn & 2.28 & 2.22 & 2.16 \\
Potensi hasil (ton ha-1) & 14 & tn & 3.38 & 3.2 & 3.49 \\
\hline
\end{tabular}

Keterangan: (tn) Tidak berbeda nyata; $\mathrm{BK}=$ bobot kering, $\mathrm{BB}=$ bobot basah, $\mathrm{TD}=$ T. diversifolia, $\mathrm{PA}=$ pupuk kandang ayam, $\mathrm{J}=$ jerami. Potensi hasil dihitung berdasarkan jumlah tanaman dalam ubinan $(2.5 \mathrm{~m}$ x $2.5 \mathrm{~m})$ x jumlah anakan produktif $\mathrm{x}$ jumlah gabah per malai $\mathrm{x}$ bobot 1000 butir

Dekomposer yang digunakan dalam penelitian ini mengandung Bacillus sp. sejumlah $1.37 \times 10^{7} \mathrm{Cfu}$ $\mathrm{g}^{-1}$. Beberapa bakteri genus Bacillus seperti Bacillus polymyxa, Bacillus laevolacticus, dan Bacillus megaterium berperan sebagai mikroorganisme pelarut fosfat. Menurut Ginting et al. (2006), tanaman memperoleh unsur P dari tanah, pemupukan, serta hasil dekomposisi dan mineralisasi bahan organik. Mikroorganisme pelarut fosfat akan mengubah fosfat yang tidak tersedia menjadi tersedia untuk memenuhi kebutuhannya, dan fosfat yang tersedia ini juga dapat diserap oleh tanaman.

Tabel 3. Komponen pertumbuhan padi dengan perlakuan aplikasi dekomposer

\begin{tabular}{|c|c|c|c|c|}
\hline \multirow[t]{2}{*}{ Peubah } & \multirow[t]{2}{*}{ Umur (MST) } & \multirow[t]{2}{*}{ Uji F } & \multicolumn{2}{|c|}{ Dosis dekomposer (\% per bahan baku) } \\
\hline & & & 0 & 0.50 \\
\hline \multirow[t]{2}{*}{ Tinggi tanaman $(\mathrm{cm})$} & 8 & $\operatorname{tn}$ & 73.05 & 73.78 \\
\hline & 14 & tn & 91.63 & 93.18 \\
\hline \multirow[t]{2}{*}{ Jumlah anakan per rumpun } & 8 & $*$ & $13.60 \mathrm{~b}$ & $15.10 \mathrm{a}$ \\
\hline & 14 & tn & 11.49 & 11.79 \\
\hline \multirow[t]{2}{*}{ Warna daun } & 5 & $*$ & $2.96 \mathrm{a}$ & $2.87 \mathrm{~b}$ \\
\hline & 8 & tn & 3.05 & 3.06 \\
\hline Panjang akar $(\mathrm{cm})$ & 8 & tn & 27.46 & 28.79 \\
\hline BB tajuk (g tanaman-1) & 8 & tn & 104.23 & 115.83 \\
\hline BB akar (g tanaman-1) & 8 & tn & 39.92 & 41.17 \\
\hline BK akar (g tanaman-1) & 8 & tn & 10.50 & 11.63 \\
\hline \multicolumn{5}{|l|}{ Kadar hara pada daun: } \\
\hline N (\%) & 8 & tn & 0.92 & 0.96 \\
\hline P (\%) & 8 & $*$ & $0.38 b$ & $0.40 \mathrm{a}$ \\
\hline K (\%) & 8 & tn & 2.79 & 3.00 \\
\hline \multicolumn{5}{|l|}{ Serapan hara: } \\
\hline $\mathrm{N}(\mathrm{g}$ tanaman- 1$)$ & 8 & $\operatorname{tn} x)$ & 0.24 & 0.29 \\
\hline $\mathrm{P}(\mathrm{g}$ tanaman- 1$)$ & 8 & $\operatorname{tn} x)$ & 0.10 & 0.11 \\
\hline $\mathrm{K}(\mathrm{g}$ tanaman- 1$)$ & 8 & $\operatorname{tn} x)$ & 0.72 & 0.87 \\
\hline
\end{tabular}

Keterangan: (tn) Tidak berbeda nyata; $(*)$ Berbeda nyata pada taraf kesalahan $\left.5 \% ;{ }^{x}\right)$ hasil transformasi $\sqrt{ }(\mathrm{x}+0.5)$, BK $=$ bobot kering, $\mathrm{BB}=$ bobot Basah 
Tabel 4. Komponen produksi padi dengan perlakuan aplikasi dekomposer

\begin{tabular}{|c|c|c|c|c|}
\hline \multirow[t]{2}{*}{ Peubah } & \multirow[t]{2}{*}{ Umur (MST) } & \multirow[t]{2}{*}{ Uji F } & \multicolumn{2}{|c|}{ Dosis dekomposer (\% per bahan baku) } \\
\hline & & & 0 & 0.5 \\
\hline Jumlah anakan produktif & 14 & tn & 10.80 & 11.40 \\
\hline Panjang malai $(\mathrm{cm})$ & 14 & $*$ & $22.91 b$ & $23.76 \mathrm{a}$ \\
\hline Jumlah gabah per malai & 14 & tn & 123.50 & 134.70 \\
\hline Bobot 1000 butir (g) & 14 & tn & 29.05 & 28.39 \\
\hline Gabah isi (\%) & 14 & tn & 87.69 & 87.13 \\
\hline Gabah hampa (\%) & 14 & tn & 11.80 & 12.17 \\
\hline Bobot kering gabah (g tanaman-1) & 14 & tn & 21.92 & 23.83 \\
\hline Bobot basah gabah petak bersih $\left(\mathrm{kg} 7.29 \mathrm{~m}^{-2}\right)$ & 14 & tn & 1.58 & 1.63 \\
\hline Bobot kering gabah petak bersih $\left(\mathrm{kg} 7.29 \mathrm{~m}^{-2}\right)$ & 14 & tn & 1.37 & 1.40 \\
\hline Produktivitas GKG (ton ha' $\left.{ }^{-1}\right)$ & 14 & tn & 2.19 & 2.25 \\
\hline Potensi hasil (ton ha-1) & 14 & tn & 3.20 & 3.51 \\
\hline Bobot brangkasan (g tanaman $\left.{ }^{-1}\right)$ & 14 & tn & 60.25 & 63.87 \\
\hline
\end{tabular}

Keterangan: (tn) Tidak berbeda nyata; $(*)$ Berbeda nyata pada taraf kesalahan 5\%

Aplikasi dekomposer dilakukan 2 minggu setelah pupuk organik diaplikasikan di lahan. Akibat aplikasi pupuk organik yang disebar, tingkat ketebalan tumpukan pupuk organik tersebut sangat kecil. Diduga interaksi antara dekomposer yang diberikan dengan bahan organik yang diaplikasikan sangat kurang sehingga aktivitas dekomposer tidak berjalan dengan baik.

Menurut Setyorini et al. (2006) tinggi timbunan bahan organik yang memenuhi syarat untuk pengomposan adalah sekitar 1.25-2.00 m. Semakin tinggi volume timbunan dibanding permukaan, semakin besar isolasi panas dan semakin mudah timbunan menjadi panas. Demikian juga apabila timbunan terlalu dangkal akan menyebabkan kehilangan panas dengan cepat karena bahan tidak cukup untuk menahan panas dan menghindari pelepasannya.

\section{Interaksi Jenis Pupuk Organik dengan Dekomposer}

Hasil analisis interaksi (Tabel 5) menunjukkan bahwa kombinasi perlakuan 5 ton ha' ${ }^{-1} T$. diversifolia dan 15 ton ha ${ }^{-1}$ pupuk kandang ayam dengan pemberian dekomposer meningkatkan bobot kering tajuk, serapan hara $\mathrm{P}$ dan serapan hara $\mathrm{K}$ pada daun sebesar $63.25 \%, 54.55 \%$ dan $33.43 \%$ lebih baik dibandingkan kombinasi lainnya. Aplikasi dekomposer diduga berperan mempercepat tingkat dekomposisi bahan organik. Asam-asam organik tanah yang dihasilkan pada dekomposisi bahan organik dapat melarutkan $\mathrm{P}$ tanah dan unsur-unsur mikro kurang terlarut sehingga menjadi tersedia bagi tanaman (Munawar, 2011).

\section{Kombinasi Jenis Pupuk dan Perlakuan Dekomposer dengan Pembanding}

Hasil uji t (Tabel 6) menunjukkan perbedaan nyata perlakuan terhadap pembanding pada beberapa peubah yaitu tinggi tanaman, jumlah anakan, dan jumlah malai. Kombinasi 5 ton $T$. diversifolia ha $^{-1}$ dan 15 ton pupuk kandang ayam ha-1 dengan aplikasi dekomposer nyata lebih baik $9.03 \%$ dan $7.25 \%$ dibandingkan ketiga pembanding pada peubah tinggi tanaman 8 dan 14 MST. Seluruh kombinasi perlakuan nyata berbeda lebih baik $54.00 \%$ dan $50.62 \%$ daripada pembanding 10 ton jerami ha ${ }^{-1}$ dengan 5 ton pupuk kandang ayam ha ${ }^{-1}$ dan 0.4 pupuk kandang ayam ha1 yang dicairkan sebagai dekomposer pada peubah jumlah anakan 3 dan 5 MST.

Pembanding 10 ton jerami dengan 5 ton pupuk kandang ayam per hektar yang diberi 0.4 pupuk kandang per hektar per hektar yang dicairkan sebagai dekomposer berpotensi memberikan hasil yang baik dilihat dari jumlah anakan produktif dan jumlah malai yang lebih banyak dibandingkan perlakuan lainnya. Skala warna daun pembanding ini menunjukkan skala yang paling rendah dibandingkan perlakuan lainnya yaitu sebesar 2.30 pada awal pengukuran dan kemudian meningkat menjadi skala 3.00 pada pengukuran selanjutnya. Pembanding ini menunjukkan warna daun yang lebih hijau dibandingkan pembanding lainnya hingga akhir fase vegetatif. Pertumbuhan vegetatif yang baik diduga akan memberikan hasil yang baik, karena pertumbuhan vegetatif yang baik mempersiapkan fase generatif yang baik pula. 
Tabel 5. Pengaruh interaksi perlakuan kombinasi jenis pupuk organik dan dekomposer terhadap beberapa karakter agronomi padi

\begin{tabular}{|c|c|c|c|}
\hline \multirow[t]{2}{*}{ Kombinasi pupuk organik (ton ha-1) } & \multicolumn{2}{|c|}{ Dosis dekomposer (\% per bahan baku) } & \multirow[t]{2}{*}{ Rataan pupuk } \\
\hline & 0 & 0.5 & \\
\hline & \multicolumn{3}{|c|}{ Bobot kering tajuk (g tanaman $\left.{ }^{-1}\right)^{*}$} \\
\hline $5 \mathrm{TD}+15 \mathrm{PA}$ & $23.45 b$ & $44.47 \mathrm{a}$ & 33.96 \\
\hline $5 \mathrm{TD}+10 \mathrm{PA}$ & $25.08 \mathrm{~b}$ & $20.93 b$ & 23.00 \\
\hline $5 \mathrm{~J}+10 \mathrm{PA}$ & $27.24 b$ & $23.93 b$ & 25.58 \\
\hline \multirow[t]{2}{*}{ Rataan dekomposer } & 25.26 & 29.77 & \\
\hline & \multicolumn{3}{|c|}{ Panjang malai $(\mathrm{cm})^{*}$} \\
\hline $5 \mathrm{TD}+15 \mathrm{PA}$ & $23.21 \mathrm{abc}$ & $24.24 \mathrm{ab}$ & 22.72 \\
\hline $5 \mathrm{TD}+10 \mathrm{PA}$ & $23.05 \mathrm{bc}$ & $22.66 \mathrm{c}$ & 22.85 \\
\hline $5 \mathrm{~J}+10 \mathrm{PA}$ & $22.46 \mathrm{c}$ & $24.36 \mathrm{a}$ & 23.41 \\
\hline \multirow[t]{2}{*}{ Rataan dekomposer } & 22.91 & 23.75 & \\
\hline & \multicolumn{3}{|c|}{ Serapan hara $\mathrm{P}\left(\mathrm{g} \operatorname{tanaman}^{-1}\right)^{*} \mathrm{x}$} \\
\hline $5 \mathrm{TD}+15 \mathrm{PA}$ & $0.09 \mathrm{~b}$ & $0.17 \mathrm{a}$ & 0.13 \\
\hline $5 \mathrm{TD}+10 \mathrm{PA}$ & $0.09 \mathrm{~b}$ & $0.08 \mathrm{~b}$ & 0.08 \\
\hline $5 \mathrm{~J}+10 \mathrm{PA}$ & $0.11 \mathrm{~b}$ & $0.09 \mathrm{~b}$ & 0.10 \\
\hline \multirow[t]{2}{*}{ Rataan dekomposer } & 0.09 & 0.11 & \\
\hline & \multicolumn{3}{|c|}{ Serapan hara $K\left(g \text { tanaman- }{ }^{1}\right)^{*} x$} \\
\hline $5 \mathrm{TD}+15 \mathrm{PA}$ & $0.58 \mathrm{~b}$ & $1.21 \mathrm{a}$ & 0.90 \\
\hline $5 \mathrm{TD}+10 \mathrm{PA}$ & $0.67 b$ & $0.66 \mathrm{~b}$ & 0.33 \\
\hline $5 \mathrm{~J}+10 \mathrm{PA}$ & $0.90 \mathrm{ab}$ & $0.75 \mathrm{ab}$ & 0.82 \\
\hline Rataan dekomposer & 0.72 & 0.87 & \\
\hline
\end{tabular}

Keterangan: Angka yang diikuti huruf yang sama menunjukkan tidak berbeda nyata berdasarkan uji DMRT pada $\left({ }^{*}\right)$ taraf kesalahan $5 \%$, $\left.{ }^{x}\right)$ hasil transformasi $\sqrt{ }(\mathrm{x}+0.5), \mathrm{TD}=$ T. diversifolia, $\mathrm{PA}=$ pupuk kandang ayam, $\mathrm{J}=$ jerami

Tabel 6. Perbandingan kombinasi perlakuan (pupuk organik dan dekomposer) dengan tiga pembanding

\begin{tabular}{|c|c|c|c|c|c|c|c|c|c|c|}
\hline \multirow[t]{3}{*}{ Parameter } & \multirow{3}{*}{$\begin{array}{l}\text { Umur } \\
\text { (MST) }\end{array}$} & \multicolumn{6}{|c|}{ Kombinasi pupuk organik (ton ha-1) } & \multicolumn{3}{|c|}{ Pembanding (ton ha-1) } \\
\hline & & \multicolumn{3}{|c|}{ Tanpa dekomposer } & \multicolumn{3}{|c|}{ Aplikasi dekomposer } & \multirow{2}{*}{$\begin{array}{l}10 \mathrm{~J}+5 \mathrm{PA} \\
+0.4 \mathrm{PAC}\end{array}$} & \multirow{2}{*}{$\begin{array}{l}10 \mathrm{~J}+5 \mathrm{PA} \\
+\mathrm{D}\end{array}$} & \multirow[t]{2}{*}{$10 \mathrm{~J}+5 \mathrm{PA}$} \\
\hline & & $\begin{array}{c}5 \mathrm{TD}+10 \\
\mathrm{PA}\end{array}$ & $\begin{array}{c}5 \mathrm{TD}+10 \\
\mathrm{PA}\end{array}$ & $5 \mathrm{~J}+10 \mathrm{PA}$ & $\begin{array}{c}5 \mathrm{TD}+15 \\
\mathrm{PA}\end{array}$ & $\begin{array}{c}5 \mathrm{TD}+10 \\
\mathrm{PA}\end{array}$ & $\begin{array}{c}5 \mathrm{~J}+10 \\
\mathrm{PA}\end{array}$ & & & \\
\hline \multirow{2}{*}{$\begin{array}{l}\text { Tinggitanaman } \\
(\mathrm{cm})\end{array}$} & 8 & 72.90 & 73.92 & 72.32 & 76.00xyz & 70.05 & $75.30 y$ & 67.80 & 69.55 & 69.70 \\
\hline & 14 & 92.01 & $92.26 z$ & $90.62 z$ & $96.20 x y z$ & 87.90 & $95.45 \mathrm{xz}$ & 81.70 & 89.70 & 84.70 \\
\hline \multirow[t]{5}{*}{ Jumlah anakan } & 3 & $8.90 x y$ & $7.70 \mathrm{x}$ & $8.60 x y$ & $8.30 x y$ & $9.10 x y$ & $8.30 \mathrm{x}$ & 5.00 & 6.70 & 7.80 \\
\hline & 4 & 9.80 & 9.80 & 11.00 & $10.50 \mathrm{x}$ & $10.00 \mathrm{y}$ & $10.80 \mathrm{x}$ & 6.50 & 10.20 & 11.10 \\
\hline & 5 & $12.20 \mathrm{x}$ & $12.70 x$ & $13.5 \mathrm{x}$ & $14.10 x$ & $12.30 \mathrm{x}$ & $14.40 x y$ & 8.10 & 10.80 & 13.10 \\
\hline & 6 & 11.70 & $13.40 \mathrm{x}$ & 15.9 & $14.60 \mathrm{x}$ & 12.30 & $14.10 \mathrm{x}$ & 10.00 & 12.10 & 12.10 \\
\hline & 14 & 11.80 & $11.30(\mathrm{x})$ & $11.4(\mathrm{x})$ & $11.40(\mathrm{x})$ & 12.20 & 11.80 & 16.60 & 11.20 & 12.10 \\
\hline \multirow[t]{2}{*}{ Warna daun } & 3 & $2.57(\mathrm{y})$ & $2.56(y z)$ & $2.58(\mathrm{yz})$ & $2.70(y z)$ & $2.67 \mathrm{x}(\mathrm{y})$ & 2.67 & 2.30 & 3.00 & 3.00 \\
\hline & 8 & 3.07 & 3.02 & 3.05 & 3.05 & 3.05 & 3.07 & 3.00 & 3.00 & 2.90 \\
\hline $\begin{array}{l}\text { Jumlah anakan } \\
\text { produktif }\end{array}$ & 14 & 10.70 & 10.80 & 10.90 & $11.10(\mathrm{x})$ & 11.70 & 11.30 & 15.60 & 11.20 & 11.40 \\
\hline Jumlah malai & 14 & 9.42 & $9.52(\mathrm{x})$ & 10.55 & $10.65(\mathrm{x})$ & $11.52 y$ & 10.47 & 15.30 & 10.10 & 8.80 \\
\hline $\begin{array}{l}\text { Panjang malai } \\
(\mathrm{cm})\end{array}$ & 14 & 23.21 & 23.05 & $22.46(y)$ & $24.24 \mathrm{z}$ & $22.66(y)$ & $24.36 z$ & 23.98 & 25.05 & 22.25 \\
\hline $\begin{array}{l}\text { Jumlah gabah } \\
\text { per malai }\end{array}$ & 14 & $127.62 z$ & $125.62 z$ & 117.28 & $136.06 \mathrm{xz}$ & 102.57 & $145.99 \mathrm{z}$ & 84.22 & 133.90 & 96.56 \\
\hline
\end{tabular}

Keterangan: $\mathrm{x}$ ) berbeda nyata dibandingkan $10 \mathrm{~J}+5 \mathrm{PA}+0.4 \mathrm{PAC}, \mathrm{y}$ ) berbeda nyata dibandingkan $10 \mathrm{~J}+5 \mathrm{PA}+\mathrm{D}, \mathrm{z}$ ) berbeda nyata dibandingkan $10 \mathrm{~J}+5 \mathrm{PA}$ pada hasil uji $\mathrm{t}$ taraf kesalahan $5 \%$, simbol dalam kurung menunjukkan hasil yang lebih baik pada pembanding, $\mathrm{TD}=\mathrm{T}$. diversifolia, $\mathrm{PA}=$ pupuk kandang ayam, $\mathrm{J}=$ jerami, $\mathrm{PAC}=$ pupuk kandang ayam dicairkan, $\mathrm{D}=$ dekomposer 
Perlakuan pembanding berupa aplikasi 10 ton jerami dengan 5 ton pupuk kandang ayam per hektar dan ditambah decomposer berupa cairan dari 0.4 ton pupuk kandang per hektar, berpotensi memberikan hasil sama baiknya dengan yang mendapat 5 ton $T$. diversifolia dengan 15 ton pupuk kandang ayam. Apabila penggunaan 0.4 ton pupuk kandang yang dicairkan sebagai dekomposer memberikan nilai yang lebih baik, maka dari sisi biaya produksi penggunaan pupuk kandang yang dicairkan ini lebih disarankan untuk digunakan dibandingkan dekomposer komersial.

\section{KESIMPULAN}

Penggunaan 5 ton $T$. diversifolia dan 10 ton pupuk kandang ayam per hektar maupun 5 ton jerami dan 10 ton pupuk kandang ayam per hektar lebih efisien dibandingkan penggunaan 5 ton $T$. diversifolia dan 15 ton pupuk kandang ayam per hektar. Produktivitas padi pada perlakuan jenis pupuk 5 ton $T$. diversifolia dan 15 ton pupuk kandang ayam per hektar, 5 ton $T$. diversifolia dan 10 ton pupuk kandang ayam per hektar serta 5 ton jerami dan 10 ton pupuk kandang ayam per hektar secara berturut-turut adalah 2.28, 2.22 dan 2.16 ton $\mathrm{ha}^{-1}$, dan secara statistik tidak berbeda nyata.

Aplikasi dekomposer meningkatkan jumlah anakan per rumpun, kadar hara $\mathrm{P}$ pada daun, dan panjang malai $11.03 \%, 5.26 \%$ dan $3.71 \%$ lebih baik dibandingkan tanpa pemberian dekomposer. Produktivitas tanaman padi yang diberi dekomposer dan yang tidak diberi dekomposer tidak berbeda yaitu masing-masing sebesar 2.25 dan 2.19 ton ha ${ }^{-1}$.

\section{DAFTAR PUSTAKA}

Badan Pusat Statistik. 2010. Tabel Hasil Sensus Penduduk 2010. http://www.bps.go.id [13 Oktober 2011].

Badan Pusat Statistik. 2010. Tabel Luas PanenProduktivitas- Produksi Tanaman Padi Seluruh Provinsi. http://www.bps.go.id. [13 Oktober 2011].
Ginting, R.C.B., R. Saraswati., dan E. Husen. 2006. Mikroorganisme Pelarut Fosfat, hal 141158. Dalam R.D.M. Simanungkalit, D.A. Suriadikarta, R. Saraswati, D. Setyorini, dan W. Hartatik. Pupuk Organik dan Pupuk Hayati. Balai Besar Penelitian dan Pengembangan Sumberdaya Lahan Pertanian. Bogor.

Hanafiah, K.A. 2005. Dasar-dasar Ilmu Tanah. Rajawali Press. Jakarta. 360 hal.

Hardjowigeno, S. 2007. Ilmu Tanah. Akademika Pressindo. Jakarta. 288 hal.

Hartatik, W. 2007. T. diversifolia sumber pupuk hijau. Warta Penelitian dan Pengembangan Pertanian 29(5):3-5.

Munawar, A. 2011. Kesuburan Tanah dan Nutrisi Tanaman. IPB Press. Bogor. 240 hal.

Makarim, A.K., Sunarno, dan Suyanto. 2007. Jerami Padi: Pengelolaan dan Pemanfaatan. Pusat Penelitian dan Pengembangan Tanaman Pangan. Badan Penelitian dan Pengembangan Pertanian. Bogor. 61 hal.

Saraswati, R., E. Santosa, dan E. Yuniarti. 2006. Organisme Perombak Bahan Organik, hal 211-230. Dalam R.D.M. Simanungkalit, D.A. Suriadikarta, R. Saraswati, D. Setyorini, dan W. Hartatik. Pupuk Organik dan Pupuk Hayati. Balai Besar Penelitian dan Pengembangan Sumberdaya Lahan Pertanian. Bogor.

Setyorini, D., R. Saraswati, dan E.K. Anwar. 2006. Kompos, hal 12-40. Dalam R.D.M. Simanungkalit, D.A. Suriadikarta, R. Saraswati, D. Setyorini, dan W. Hartatik (Eds.). Pupuk Organik dan Pupuk Hayati. Balai Besar Penelitian dan Pengembangan Sumberdaya Lahan Pertanian. Bogor. 